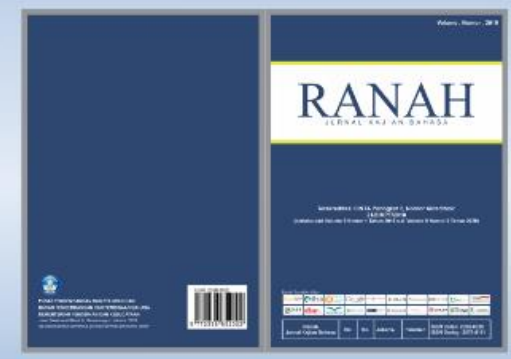

\title{
BAHASA SAKAI SEBAGAI VARIASI MELAYU: \\ TINJAUAN ASPEK LINGUISTIK DIAKRONIS
}

Sakai Language as a Malay Variation: Diacronic Linguistics Studies

\author{
Burhanuddin \\ Universitas Mataram \\ Jalan Majapahit No.62, Gomong, Kota Mataram, Nusa Tenggara Barat, Indonesia \\ burhanuddin.fkip@unram.ac.id
}

Naskah Diterima Tanggal 24 Juni 2018—Direvisi Akhir Tanggal 13 Oktober 2021—Disetujui Tanggal 11 Desember 2021 doi: https://doi.org/10.26499/rnh/v10i2.859

\begin{abstract}
Abstrak
Tulisan ini bertujuan menjelaskan bukti linguistik (fonologi dan leksikon) yang menunjukkan bahasa Sakai sebagai salah satu variasi Melayu secara linguistik diakronis. Secara metodologis, data dikumpulkan menggunakan metode dokumentasi berupa Proto-Melayu (PM) dan Kamus Bahasa Sakai. Data yang terkumpulkan kemudian dianalisis menggunakan pendekatan top-down metode inovasi bersama (shared innovations). Berdasarkan kenyataan bahwa ditemukan inovasi dan retensi fonologi PM ke dalam BS masing-masing baik bersifat teratur (korespondensi) maupun tidak teratur (variasi) Di samping itu, retensi bidang leksikon menguatkan BS sebagai salah satu varian Melayu. Hasil perbandingan BS dengan bahasa Minangkabau (MIN) ditemukan cukup banyak korespondensi dan variasi baik yang bersifat inovasi maupun variasi yang menyiratkan bahwa kedua isolek tersebut adalah varian dari bahasa yang sama, meskipun terdapat perbedaan antara kedua isolek tersebut. Hal ini menguatkan pandangan bahwa bahasa Sakai merupakan salah satu varian bahasa Melayu.
\end{abstract}

Kata-kata Kunci: variasi Melayu, linguistik diakronis, inovasi bersama, fonologi, leksikon

\begin{abstract}
This paper intends to explain the linguistic evidence (phonology and lexicon) which shows Sakai language as one of the diachronic linguistic Malay variations. Methodologically, data is collected using documentation method of Proto-Melayu (PM) and Sakai Language Dictionary. The collected data is then analyzed using a top-down approach of joint innovation methods. Based on the fact that the innovation and retention of phonology of $P M$ in their respective BS are both regular (correspondence) and irregular (variation) In addition, the retention of the lexicon field reinforces the $B S$ as one of the Malay variants. The comparison of BS with Minangkabau (MIN) language found quite a lot of correspondences and variations of both innovation and variation which implies that both isolates are variants of the same language, although there is a difference between the two isolates. This reinforces the view that the Sakai language is one of the Malay language variants.
\end{abstract}

Keywords: Malay variety, linguistics diakronic, shared innovation, phonology, lexikon.

How to Cite: Burhanuddin. (2021). Bahasa Sakai Sebagai Variasi Melayu: Tinjauan Aspek Linguistik Diakronis. Ranah: Jurnal Kajian Bahasa, 10(2), 326-340. doi: https://doi.org/10.26499/rnh/v10i2.859

\section{PENDAHULUAN}

Klasifikasi dan pemetaan bahasa-bahasa nusantara (bahasa-bahasa daerah yang ada di Indonesia khususnya), merupakan tugas berat yang harus dipikul, karena pembicaraan terhadapnya belumlah tuntas. Meskipun pengkajian terhadap rumpun bahasa Austronesia ini sudah dikaji oleh ahli linguistik sejak tahun 1784 (pada tahun tersebut Hervas Panduro 
menentukan rumpun Austronesia serta Dyen (1971), Blust (1993, 2009, dan 2012), Nothofer (1992), Adelaar (2005), Donohue dan Grimes (2008), dan Schapper (2011), tetapi perdebatan mengenai pencabangan rumpun bahasa Austronesia masih berlangsung, misalnya pengelompokkan terhadap beberapa bahasa Austronesia seperti rumpun bahasa Melayu (misalnya, terdapat istilah Melayu dan Melayik dalam kajian rumpun Melayu meskipun kedua istilah itu dibedakan, penggunaan istilah bahasa/rumpun Melayu dalam tulisan ini mengacu pada Melayu dalam arti luas (mencakup kedua istilah itu)) masih belum jelas (Collins, 1983:86 dan Blust, 2013), dan sampai sekarang belum terbit sebuah buku pun yang menyajikan sejarah bahasa Indonesia, Malaysia, Brunei, dan Singapura secara komprehensif dan ilmiah. Ada istilah Melayu dan Melayik dalam kajian rumpun Melayu. Walaupun kedua istilah itu dibedakan, penggunaan istilah bahasa/rumpun Melayu dalam tulisan ini mengacu pada Melayu dalam arti luas (mencakup kedua istilah itu).

Sebagai sumbangan kecil dalam usaha menambah pengetahuan mengenai rumpun Austronesia, di sini disajikan beberapa catatan mengenai bahasa Sakai yang digunakan oleh sejumlah penutur di Riau (Daratan). Kajian ini tidak lain sebagai upaya seperti yang dilakukan para linguis lainnya terhadap persebaraan cabang-cabang bahasa Melayu yang ada di Nusantara, seperti Nothofer (1995) tentang The History of Jakarta Malaya, Collins (1983 \& 1994) tentang Penggolongan Bahasa Melayu Bacan dan Dialek Melayu di Kalimantan, dan Bahasa Bacan: Misanan atau Mindoan, Fernandez (1997 dan 1998) tentang Wajah Melayu pada Bahasa Manado dan Bahasa Nagi Kajian Aspek Diakronis Perbandingan Dua dialek Melayu di Kawasan Timur Indonesia di Bidang fonologi, Morfologi, dan leksikon; Melayu Larantuka di Flores Timur: Sebuah Tinjauan dari Persfektif Sejarah; dan Beberapa Catatan tentang Bahasa Melayu Dilli: Studi Awal Mengenai Bahasa Melayu di Timor Timur. Begitu juga dengan kegiatan yang dilakukan Adelaar (1992) dengan membandingkan enam isolek Melayu lainnya (Melayu Standard, Minangkabau, Serawai, Iban, Banjar Hulu, dan Melayu Jakarta) untuk merekonstruksi apa yang disebutnya Proto Malayik (PM).

Kegiatan itu tidak lain diarahkan pada upaya mencari mata rantai persebaran bahasa Melayu, migrasi bahasa melayu, rekonstruksi bahasa melayu purba, juga dalam kaitannya dengan Proto-Melayu-Polinesia dan Proto Austronesia pada tingkat yang lebih tinggi, sekaligus melihat kedudukan masing-masing variasi Melayu tersebut dan keterhubungannya dengan bahasa Melayu lainnya.

Terlepas dari masalah berapa besar sumbangan dan tambahan informasi yang diberikan oleh karya-karya tersebut untuk memahami tingkat kekerabatan bahasa-bahasa Melayu/Malayik, apabila dilihat dari besarnya jumlah bahasa/dialek Melayu, tentu ada sejumlah bahasa atau dialek yang belum terekonstruksi, sehingga belum jelas pula posisi dan status kekerabatannya, salah satunya termasuk bahasa Sakai.

Nothofer (1988) mengakui bahwa, dalam karyanya A Discussion of Two Austronesian Subgroups: Proto-Malay and Proto-Malayic atas disertasinya (1975) Proto-Melayo-Javanic yang terpaku pada pengelompokkan Dyen yang disebut Gugus Jawa-Sumatra tidak mengambil Iban, Maloh, Selako, Besemah, Serawai, bahasa Aceh, sebagai bahan perbandingan yang diandaikan mempunyai kekerabatan lebih dekat dengan bahasa Melayu, yang dikritik Blust (1988). Begitu juga Adelaar (1992) dalam Proto-Malayik-nya pun melewatkan beberapa bahasa Melayu yang lain seperti Melayu Larantuka, Melayu Kupang, Melayu Ambon, Melayu Bacan, Melayu Menado, Melayu Makasar, Kutai, dan beberapa bahasa Melayu di Kalimantan yang diandaikan sebagai anggota kelompok Melayu di samping beberapa bahasa Melayu yang lain di Sumatra seperti bahasa Kerinci, Besemah, Rejang, dan lain-lain.

Meskipun dari telaah kualitatif terlewatkannya beberapa angggota bahasa yang diandaikan sekelompok dianggap sudah terwakili oleh beberapa bahasa yang telah dipilih 
sedemikian rupa untuk data rekonstruksi, namun dari segi kuantitatif bahasa-bahasa yang terlewatkan tersebut tidak mungkin didiagramkan dalam bentuk silsilah kekerabatan antara bahasa yang direkonstruksi. Dalam hubungan ini dapat dipahami apabila dalam Proto Malayic Adelaar (1992) tidak dijumpai diagram silsilah kekerabatan antarbahasa kelompok Melayu sebab, (1) tidak semua bahasa-bahasa Melayu di lingkungan Nusantara dijadikan data rekonstruksi (hanya bahasa Minangkabau, Serawai, Melayu Jakarta, Melayu Standard, Banjar, dan Iban), dan (2) akibatnya tidak ada gunanya membuat sebuah diagram silsilah kekerabatan yang hanya mencakupi beberapa bahasa saja (bandingkan dengan Kawi, 1991). Karena sesungguhnya sangat ideal apabila dalam setiap kajian rekonstruksi protobahasa tidak hanya menyajikan bukti-bukti kualitatif yang datanya diambil dari semua bahasa yang diandaikan berkerabat, tetapi juga menyajikan diagram silsilah kekerabatannya.

Oleh karena itu, kajian terhadap bahasa Sakai (BS) dari aspek linguistik diakronis (baik penentuan apakah BS termasuk salah satu variasi Melayu, ataupun penentuan hubungan BS dengan bahasa-bahasa Melayu/Melayik lainnya), selain memperkaya khasanah, juga tersedianya kajian ke-Melayu-an secara komprehensif yang sifatnya diakronis. Dengan demikian, bahasa Sakai dapat diperhitungkan dalam rumpun Melayu dalam kajian linguistik diakronis terhadap bahasa-bahasa Melayu yang ada, baik dalam hal rekonstruksi, asal mula penutur Melayu, gerak migrasi, maupun klasifikasi dan penetapan tingkat kekerabatan terhadap bahasa-bahasa Melayu secara keseluruhan.

Bahasa Sakai (BS) adalah bahasa yang digunakan oleh orang Sakai yang hidup terpencar di Mandau, Minas, Dumai, dan Bukit Kapur Kabupaten Bengkalis, Riau (bandingkan Lubis dkk, 1985; Gani dkk, 1985; dan Martono dkk, 1995 dengan Kalipke, 2003). Menurut Martono dkk (1995), suku Sakai merupakan suku asli Riau di samping suku Melayu yang terdapat di Riau Daratan. Sebagian suku Sakai masih hidup terpencar di dalam hutan (pedalaman), sebagian sudah dimukimkan, dan sebagaian sudah hidup berintegrasi dengan penduduk di luar sukunya (bandingkan dengan Kompas, 2003).

Sejauh Pengamatan penulis, pengkajian terhadap bahasa Sakai selama ini lebih bersifat sinkronis, hal ini dapat dilihat dari beberapa hasil penelitian yang berkaitan dengan bahasa Sakai yaitu Struktur Bahasa Sakai (Lubis dkk, 1985), Kamus Sakai - Indonesia (Gani dkk, 1985), Morfologi dan Sintaksis Bahasa Sakai (Martono dkk, 1995), dan Kamus Sakai Indonesia - Jerman (Kalipke, 2003).

Hal menarik dari keempat hasil penelitian yang bersifat sinkronis di atas, dikatakan bahwa, bahasa Sakai memiliki persamaan dengan dialek Melayu dan Minangkabau (MIN). Untuk memperjelas berikut kutipan pernyataan.

“... bahasa Sakai memiliki banyak persamaan dengan beberapa dialek bahasa Melayu antara lain Kuantan dan Minangkabau." (Gani dkk, 1985).

"... bahasa Sakai ada persamaan dengan bahasa Melayu dan bahasa Minangkabau. Penduduk Kecamatan Mandau pada umumnya dapat berbahasa Melayu dan berbahasa Minangkabau." (Lubis dkk, 1985:1).

“... lafal, kata, dan strukturnya hampir sama dengan lafal, kata, dan struktur bahasa Melayu dan bahasa Minangkabau." (Martono dkk, 1995:1)

Kutipan di atas menyuratkan dua hal pertama BS merupakan bahasa Melayu (salah satu variasi Melayu) dan kedua BS lebih dekat bahasa Melayu dan bahasa Minangkabau (hubungan BS dialek Melayu lainnya).

Namun sejauh ini belum ada upaya pembuktian/kajian secara linguistis diakronis untuk membuktikan dua hal yang tersurat dalam pernyataan di atas. Pernyataan Kalipke dalam Harian Kompas edisi 03 Januari 2003 menguatkan pernyataan di atas sekaligus memperjelas kedudukan bahasa Sakai sebagai salah satu variasi Melayu dengan diterbitkannya sebuah kamus bahasa Sakai yang dikarangnya. Menurut Kalipke (2003) dari Kamus Sakai yang 
disusunnya dapat diteliti asal muasal bahasa Melayu yang kemudian menjadi bahasa nasional bangsa Indonesia. Seperti halnya tiga linguis di atas, pendapat antropolog Jerman ini pun tidak ditopang oleh kerangka kerja dalam kajian linguistik diakronis yang kontemporer baik secara teoretis maupun metodologis sebagaimana layaknya, baik dalam hal penentuan asal bahasa modern, yaitu apakah isolek-isolek Melayu warisan atau bukan; serta tidak adanya pembuktian hubungan BS dengan isolek-isolek Melayu lainnya (dalam hal ini hubungan dengan Melayu Standard dan Minangkabau). Istilah Melayu Standard digunakan untuk mengacu pada Melayu Riau dan Melayu yang digunakan di Istana Kesultanan Johor, yang kemudian sebagai bentuk/cikal bakal bahasa Indonesia dan bahasa Malaysia.

Hal ini sangat disadari bahwa, umumnya antropolog tidak dibekali kerangka berpikir secara linguistis (diakronis) dalam penentuan keasalan, penggolongan, dan penentuan hubungan suatu bahasa. Para antropolog untuk mencapai pada kesimpulan di atas lebih didasarkan/dengan menggunakan metode pemeriksaan sekilas (by inspection method), yaitu dengan melihat kemiripan bentuk kosa katanya secara sekilas, atau si pengamat hanya mengadakan peninjauan sepintas lalu mengenai persamaan dan perbedaan antara bahasabahasa yang dibandingkan (Keraf, 1984:112).

Seandainya asumsi di atas kita terima, yakni bahwa bahasa Sakai sebagai salah satu variasi Melayu, maka atas dasar apa kita dapat mengatakan bahwa bahasa Sakai merupakan variasi Melayu? Berkaitan dengan penentuan bahasa Sakai sebagai salah satu variasi Melayu secara diakronis, ada dua pertanyaan mendasar yang harus dijawab, yaitu (1) apakah bukti linguistis yang menandai bahasa Sakai merupakan warisan dari Proto Melayu/Malayik?, dan (2) jika bahasa Sakai merupakan kelanjutan Proto Malayik, bagaimanakah hubungannya dengan isolek-isolek Melayu lainnya? Dengan kata lain misalnya dengan isolek Melayu manakah variasi Melayu Sakai memiliki hubungan yang paling dekat? Jawaban atas pertanyaan kedua sekaligus dapat menjawab apakah BS lebih mirip dengan Melayu Standard atau Minangkabau. Sehingga kita dapat mempertentangkan apakah bahasa Sakai (yang secara administratif masuk dalam propinsi Riau) lebih dekat dengan Melayu Riau (yang juga suku asli di Riau) atau lebih dekat dengan bahasa Minangkabau (sebagai pendatang). Agar (dalam Kompas, 2003) menyatakan ada tiga hal yang mengancam keberadaan bahasa Sakai yaitu keberadaan suku pendatang (Minangkabau, Batak, Melayu, dan Jawa) yang menetap di propinsi Riau, hilangnya hutan, dan adanya rasa malu anak-anak muda Sakai untuk menggunakan bahasa mereka. Lihat Nadra (1997) bahwa bahasa Minangkabau juga memiliki daerah pakai apa yang disebut daerah Luhak dan daerah Rantau (salah satunya Riau). Oleh karena itu, tulisan ini mencoba menjawab kedua persoalan di atas dari aspek linguistik diakronis.

Dalam Kaitannya dengan kedudukan BS dalam rumpun Austronesia, Haudricourt (dalam Anceaux, 1981) sedikit menyinggung bahwa bahasa Austronesia di Kawasan Vietnam dikelompokkan ke dalam kelompok Nusantara bagian selatan, karena keadaan kebahasaannya sama seperti di Semenanjung Malaya tempat masuknya bahasa Austronesia di waktu itu, yaitu bahasa-bahasa asli (Semang, Sakai) yang dikelompokkan ke dalam bahasa Austro-Asia.

Lebih lanjut dalam klasifikasi Keraf (1984:209), bahasa Sakai masuk dalam bahasabahasa Auronesia Barat dalam hal ini bahasa-bahasa Hesperonesia (Indonesia Barat) yang kemudian dikelompokkan dalam kelompok bahasa Minangkabau. Bahasa Minangkabau oleh Keraf (1984) dibagi menjadi tiga yaitu Agam (Payakumbuh, Agam), Tanah Datar (si Junjung, Batu Sangkar - Pariangan, Singkarak), dan Kerinci (Lubu, Ulu, Mamaq, akit, Rawa, Talang, Sakai, Mokomoko).

Dalam penelitian Dahlan dkk (1985:10-12) tentang Pemetaan Bahasa Daerah Riau dan Jambi secara garis besar dikemukakan bahwa bahasa daerah yang dipakai oleh masyarakat Riau di Kabupaten Bengkalis adalah Melayu Riau. Adapun bahasa-bahasa daerah di 
Kabupaten Bengkalis terdiri dari bahasa Bagansiapiapi, bahasa Bengkalis, bahasa Selatpanjang, bahasa Siak, dan bahasa Sungaiapit. Tetapi dalam kajian itu tidak disinggung sedikitpun perihal keberadaan bahasa Sakai, yang secara administratif masuk dalam Kabupaten Bengkalis. Ada beberapa kemungkinan tidak disinggungnya bahasa Sakai dalam penelitian ini, pertama bahasa Sakai luput dari perhatian peneliti (terkait dengan sampel dan populasi) dan kedua ada kemungkinan bahasa Sakai memiliki banyak perbedaan dengan bahasa-bahasa/dialek-dialek Melayu yang ada di Riau, sehingga tidak dapat digolongkan ke dalam dialek Melayu Riau. Jika bahasa Sakai diandaikan memiliki hubungan dengan dialek Melayu seperti pernyataan beberapa linguis di atas, lalu mengapa dalam penelitian Dahlan dkk (1985), bahasa Sakai tidak disinggung sedikitpun? Seperti halnya juga bahasa Kuantan yang secara administratif masuk ke dalam Kabupaten Indragiri Hulu (salah satu Kabupaten di Riau), Dahlan dkk (1985) pun tidak menyinggung sedikit pun perihal bahasa Kuantan dalam hasil identifikasi dan pemetaannya terhadap seluruh bahasa di kabupaten ini, yang oleh Gani dkk (1985) diasumsikan memiliki kesamaan/hubungan yang lebih dekat dengan BS. Sedangkan Nadra (1997) menyatakan Kuantan termasuk salah satu wilayah pakai/ber-penutur bahasa/dialek Minangkabau.

Lebih lanjut, Nadra (1997) dalam disertasinya tentang Geografi Dialek Bahasa Minangkabau, menjelaskan bahwa wilayah bahasa Minangkabau tidak hanya terbatas pada batas administratif Provinsi Sumatra Barat, dan bahkan dalam peta pemakaian bahasa Minangkabau mencakup sebagian besar Provinsi Riau Daratan dan Provinsi Jambi, sebelah barat Bengkulu, Sumatra Barat hingga Aceh, dan Negeri Sembilan di Malaysia. Kesemua daerah itu termasuk dalam daerah Rantau yang juga menggunakan isolek Minangkabau. Sehingga beberapa kajian di atas masih mengaburkan pemahaman kita tentang identitas kemelayuan dan hubungan bahasa Sakai dengan isolek-isolek Melayu lainnya.

\section{LANDASAN TEORI}

Sesuai dengan tujuan tulisan ini, masalah hubungan antarbahasa sekerabat dalam telaah komparatif pada prinsipnya dapat dibuktikan berdasarkan unsur-unsur warisan dari bahasa asal atau proto bahasa (proto-language) (Fernandez, 1996:21). Pengamatan terhadap perangkat kognat mempunyai relevansi historis dapat diformulasikan kaidah-kaidah perubahan bunyi yang teratur atau korespondesi fonem antarbahasa sekerabat. Sehingga berdasarkan pemahaman terhadap kaidah perubahan bunyi yang teratur dapat dilakukan pemilihan kata-kata bahasa sekarang yang merupakan kelanjutan dari bahasa asalnya (Dyen, 1978:34 dalam Fernandez 1996:21).

Secara genetis pengelompokkan bahasa dalam telaah komparatif dapat menyajikan keterangan tentang hubungan historis bahasa-bahasa sekerabat secara khusus, bahwa pengelompokkan harus berdasarkan bukti-bukti berupa inovasi bersama secara ekslusif (exclusively shared innovations) (Brugmann, 1884 dalam Fernandez 1996). Istilah inovasi berarti pembaharuan, yaitu perubahan yang memperlihatkan penyimpangan dari kaidah yang lazim berlaku. Istilah retensi dibedakan dengan istilah inovasi karena retensi merupakan unsur warisan dari bahasa asal yang tidak mengalami perubahan pada bahasa sekarang (Fernandez, 1996).

Sejumlah inovasi yang ditemukan pada bahasa-bahasa turunan, senantiasa memperlihatkan pula kesamaan pola dan ciri-ciri perubahan. Di antara perubahan itu, ada yang hanya ditemukan pada bahasa atau bahasa-bahasa tertentu, dan perubahan itu bersifat eksklusif. Ciri-ciri perubahan bersama yang eksklusif (exclusively shared innovation) baik yang teratur mapun yang tidak teratur pada tataran fonologi dan perangkat leksikon yang hanya ditemukan pada bahasa-bahasa tertentu, atau juga unsur-unsur morfologis, dapat dijadikan bukti keeratan hubungan bahasa-bahasa kerabat (Jeffers dan Lehiste, 1979:31 serta 
Mbete, 1990). Dengan demikian, semakin banyak kaidah perubahan yang ditemukan dan dimiliki bersama, maka semakin kuat pula bukti-bukti keeratan hubungan ke subkelompokkan bahasa kerabat (Bynon, 1979:64, dalam Mbete, 1990).

Dalam tulisan ini, karena inovasi fonologis pada dua bahasa yang sekerabat atau lebih (misalnya substitusi $* \mathrm{j}>\mathrm{g}$ (dibaca bunyi /j/ purba berubah menjadi /g/) yang dialami dua bahasa yang terpisah secara geografis, seperti yang terjadi pada bahasa Palau Perintang-Batak di satu pihak dan kelompok Filipina di pihak lain), dapat ditafsirkan sebagai dua inovasi yang terjadi secara terpisah (Nothofer, 1986:13 dalam Fernandez, 1996), maka "penetapan" bahasa Sakai tidak cukup dengan inovasi fonologis secara eksklusif, tetapi perlu dukungan inovasi leksikal. Jadi, tulisan ini hanya menggunakan bukti inovasi fonologis dan inovasi leksikal untuk menentukan apakah bahasa Sakai merupakan kelanjutan Proto Malayik atau bukan, maupun dalam menentukan hubungan yang lebih dekat antara bahasa Sakai dengan isolekisolek Melayu lainnya.

Penelitian relevan yang lebih mutakhir dilihat dari aspeknya pengkajiannya adalah Sarwadi, Mahsun, dan Burhanuddin (2019), Hadi, Burhanuddin, dan Sukri (2020); Sumarlam, Purnanto, dan Burhanuddin (2018); serta Sumarlam dkk (2017a dan 2017b). Penelitian Sawardi, Mahsun, dan Burhanuddin (2019) bertujuan menjelaskan tentang variasi leksikon dalam bahasa Sasak. Penelitian Hadi, Burhanuddin, dan Sukri (2020) bertujuan menjelaskan ciri Subrumpun Halmahera Selatan-Papua Barat yang tercermin dalam bahasa Maya. Penelitian Sumarlam, Purnanto, dan Burhanuddin (2018) bertujuan menguji hipotesis Collins (1981) dengan melihat reflex Proto-Austronesia ke dalam bahasa Ambelau. Penelitian Sumarlam dkk (2017a) bertujuan menjelaskan pentingnya mengkaji Kelompok Maluku Tengah Barat. Adapun Sumarlam dkk (2017b) bertujuan menjelaskan hipotesis Collins (1981) yang tercermin dalam bahasa Buru. Jika dilihat dari objeknya, penelitian-penelitian tersebut berbeda dengan penelitian ini meskipun dalam aspeknya beberapa di antaranya mengandung kemiripan.

\section{METODE PENELITIAN}

Adapun metode yang digunakan adalah metode komparatif yang bersifat kualitatif yaitu Top-Down Reconstruction Method (pendekatan dari atas ke bawah) yaitu berkaitan dengan penentuan refleks fonem pada bahasa yang merupakan anggota Austronesia dan Malayik. Peninjauan hubungan antarprotobahasa pada dua peringkat yang berbeda yang tertinggi PAN yang disusun Dempwolf (1938) yang telah direvisi Dyen (1971) dan Blust (1988). dan peringkat yang lebih rendah Proto Malayik (PM) yang disusun Adelaar (1992).

Adapun data perbandingan, untuk bahasa Sakai telah dimanfaatkan kamus bahasa Sakai yang disusun Gani dkk (1985) dan data yang dikumpulkan Adelaar. Kemudian data yang ada dalam kamus tersebut dibandingkan dengan Proto Malayik dan isolek Melayu lainnya terutama terhadap dua isolek Melayu yang diduga memiliki hubungan yang erat dengan bahasa Sakai yaitu Melayu Standard dan Minangkabau.

\section{PEMBAHASAN}

\section{Bahasa Sakai sebagai Kelanjutan Proto Malayik}

Ada beberapa alasan linguistik yang akan diajukan untuk membuktikan bahwa bahasa sakai merupakan salah satu variasi Melayu, yaitu bukti fonologi dan bukti leksikal baik yang berupa retensi maupun inovasi, dengan melihat refleks fonem/etimon proto baik Proto Austronesia (PAN) maupun Proto Malayik (PM) yang tercermin dalam bahasa Sakai. Namun, dalam tulisan ini tidak semua fonem diperikan sebagai contoh refleksi, hanya yang menarik saja yang disajikan. 


\section{a. Bukti Fonologi}

Bahasa Sakai (BS) merupakan salah satu variasi Melayu berdasarkan pengama-tan bahwa PAN *a menjadi BS : a (PAN *a > BS : a /\#(K)V(K) - ) pada posisi penultima terbuka/tertutup muncul secara teratur hal ini terjadi pada semua isolek Melayu, yang dalam bahasa Melayu (Melayu Standard (MS)) mengalami retensi pada semua posisi.

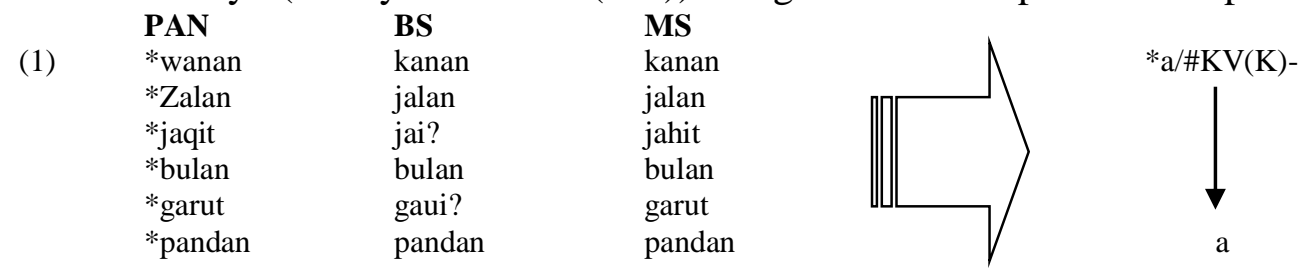

Dari data (1) menunjukkan bahwa BS bersama dengan bahasa Melayu (MS) merefleksikan fonem /a/ dalam pada PAN : *a. Perihal adanya data *b $\partial$ Rat $>$ b $\supset$ e? 'berat', dapat diterangkan bahwa PAN : *a menjadi a, $\supset$, dan e dalam BS pada posisi ultima terbuka/tertutup (PAN : *a > BS: a, $\supset$, dan e) terjadi secara teratur berupa inovasi split, sedangkan dalam bahasa Melayu Standard tetap mempertahankan fonem /a/.

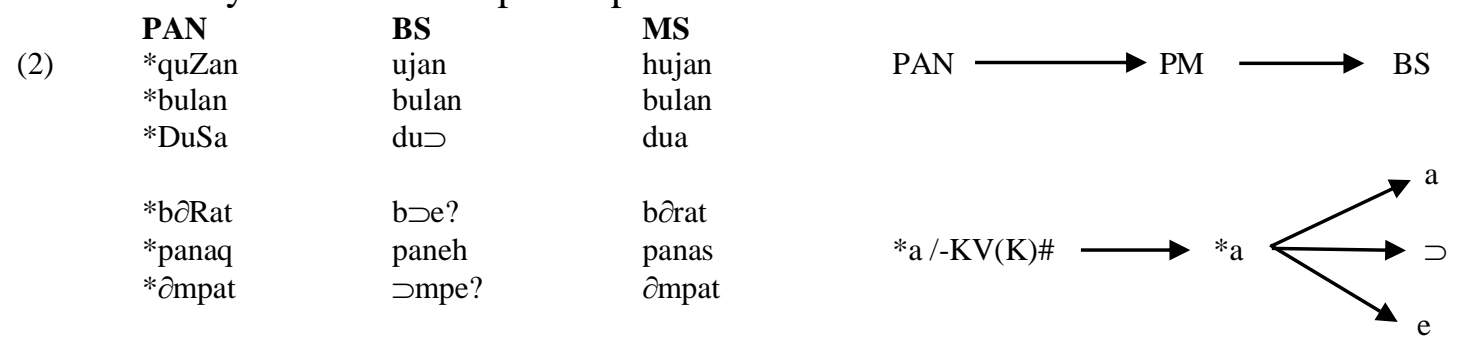

Dalam BS masih banyak ditemukan contoh PM: *a > BS: a, つ, dan e, pada posisi ini

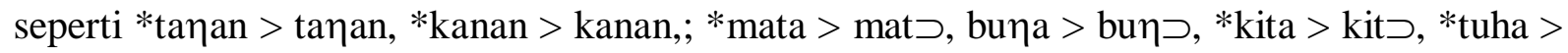

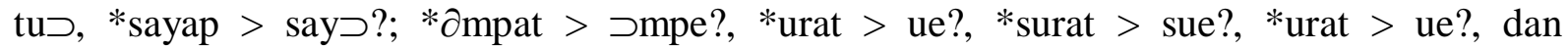
sebagainya.

Seperti yang dikemukakan Dempwolf (1937:21 dalam Collins, 1983) bahwa dalam bahasa Melayu terjadi beberapa inovasi berupa penyatuan (merger) dari PAN, salah satunya berupa *r, *R, > r. Dalam BS mengalami inovasi berupa pelesapan pada semua posisi secara teratur. Lenyapnya PAN : *r, *R mungkin tidak terjadi secara serentak dalam BS, mungkin melalui fase historis tertentu terjadi inovasi yaitu PAN * $\mathrm{r}, * \mathrm{R}>\mathrm{PM}$ : ${ }^{\mathrm{r}} \mathrm{r},{ }^{*} \mathrm{R}>*_{\mathrm{r}}$ (fase historis tertentu) > BS: $\phi$.

\begin{tabular}{|c|c|c|c|}
\hline \multirow{6}{*}{ (3) } & PAN & BS & MS \\
\hline & *ka-wiRi & kii & kiri \\
\hline & *ikuR & iku & ekor \\
\hline & *ukir & uki & ukir \\
\hline & *Ratus & atuih & ratus \\
\hline & $*_{\text {jari }}$ & jai & jari \\
\hline
\end{tabular}

Selain itu, seperti halnya dalam bahasa Melayu Standard, BS masih merefleksikan /p/ (mengalami retensi, yaitu PAN: *p > BS: $p$ ).

$\begin{array}{lll}\text { (4) } & \text { BAN } & \text { MS } \\ \text { *pandan } & \text { pandan } & \text { pandan } \\ \text { *putiq } & \text { putih } & \text { putih } \\ \text { *pajoy } & \text { padi } & \text { padi } \\ \text { *qat } \partial \text { p } & \text { at } \supset \text { ? } & \text { atap } \\ \text { *is } \partial \text { p } & \text { is } \supset ? & \text { (h)isap }\end{array}$

Namun, pada posisi ultima tertutup yang berakhir dengan $/ \mathrm{p} /, / \mathrm{t} /$, dan $/ \mathrm{k} /$ mengalami inovasi berupa merger (penyatuan) terjadi secara teratur dari PAN, PM ke dalam BS. 
(5)

\begin{tabular}{|c|c|}
\hline PAN & PM \\
\hline$*$ qat $\partial \mathrm{p}$ & *hat $\partial \mathrm{p}$ \\
\hline$* a s \partial \mathrm{p}$ & $*$ as $\partial \mathrm{p}$ \\
\hline *bəRat & *borat \\
\hline *jaqit & *jahit \\
\hline *Rusuk & *rusuk \\
\hline
\end{tabular}

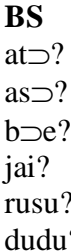

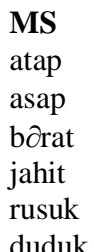

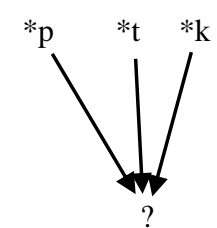

Perihal adanya sejumlah data yang tetap mempertahankan /p/ pada posisi ini, misalnya idup, $l \supset \eta k a p, l \supset>a p, s \supset d a p$ diduga bentuk ini sebagai bentuk pinjaman.

Di antara perubahan kecil yang sering ditemui di dalam perbandingan bahasa terdapat metatesis. Dempwolf (1937:21, dalam Collins, 1983:105) menyebutkan dua contoh metatesis di dalam bahasa Melayu dari PAN. Hal ini terjadi pada bahasa Sakai.

(6)

$\begin{array}{lll}\text { PAN } & \text { BS } & \text { MS } \\ \text { *dilaq } & \text { lidah } & \text { lidah } \\ \text { *quDip } & \text { idup } & \text { hidup }\end{array}$

Inovasi lainnya berupa penyatuan (merger) PAN: *i, *iw, *uy > i dalam bahasa Melayu pada posisi akhir terjadi secara teratur, begitu juga dalam BS.

$\begin{array}{ll}\text { PAN } & \text { BS } \\ \text { *ka-wiRi } & \text { kii } \\ \text { *daki } & \text { daki } \\ \text { *nipi } & \text { mimpi } \\ & \\ \text { *baRiw } & \text { basi } \\ \text { *Xapuy } & \text { api } \\ \text { *babuy } & \text { babi }\end{array}$
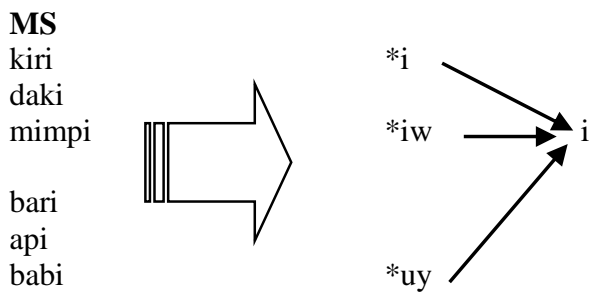

Ada juga kata beberapa kosa kata yang berakhir dengan PAN: *ay atau * $\partial y$ yang berubah menjadi /i/ juga dalam bahasa Melayu. Maka dalam BS semua kata jenis ini juga berubah menja-di /i/, misalnya PAN: *mat $\partial y$ > BS: mati, PAN: *qatoy > BS: ati. Kesepadanan di dalam peru-bahan yang begitu khas ini merupakan bukti penting yang menunjukkan hubungan bahasa Melayu dan bahasa Sakai; serta hubungan proto Austrionesia dan proto Malayik dengan bahasa Sakai.

Pada tingkat yang lebih rendah dari PAN, untuk membuktikan bahwa bahasa Sakai merupakan salah satu variasi Melayu, ditemukan adanya sejumlah refleks fonem PM ke dalam BS baik berupa retensi maupun inovasi. Etimon Proto yang digunakan adalah PM yang disusun Adelaar (1992), yang diasumsikan telah menurunkan bahasa-bahasa Melayu yang ada sekarang.

Adanya inovasi berupa substitusi (penggantian) secara teratur yang terjadi dari PM: *a menjadi $\supset$ dalam BS pada posisi ultima terbuka dan tertutup selain fonem $/ \mathrm{t} / \mathrm{yang}$ berkorespon-densi dengan a dalam MS (karena MS: a < PM: *a (mengalami retensi)). Perhatikan contoh.

\begin{tabular}{|c|c|c|c|}
\hline \multirow[t]{4}{*}{ (8) } & $\begin{array}{l}\mathbf{P M} \\
*_{\text {mata }}\end{array}$ & $\begin{array}{l}\text { BS } \\
\text { mat } \supset\end{array}$ & $\begin{array}{l}\text { MS } \\
\text { mata }\end{array}$ \\
\hline & $*$ tuha & tuつ & tua \\
\hline & *kita & אit & kita \\
\hline & *dua & du & dua \\
\hline
\end{tabular}


Terjadinya inovasi berupa merger (penyatuan) dalam PM: *a, *e > BS: a /-KVK\#, yang oleh Adelaar (1992) tetap dipertahankan sebagai /a/ dalam MS.

(9)

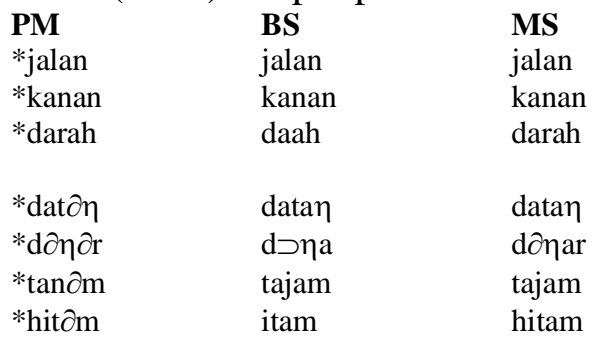
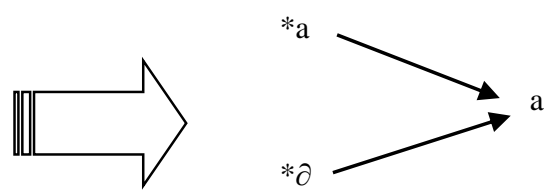

Namun, PM: *a, dan *d tidak lagi menjadi BS: a, apabila pada PM-nya berakhir dengan konsonan /t/, akan menjadi e $\left(* a, * \partial>\right.$ e/-KVK $\left.{ }_{+} \#\right)$ yang berkorespondesi dengan MS: a.

\begin{tabular}{|c|c|c|c|}
\hline \multirow{3}{*}{ (10) } & PM & BS & MS \\
\hline & $* \partial \mathrm{mpat}$ & $\supset$ mpe? & $\partial \mathrm{mpat}$ \\
\hline & *urat & ue? & urat \\
\hline & *surat & sue? & surat \\
\hline & $*$ bul $\partial \mathrm{t}$ & bつle? & bulat \\
\hline & $* \mathrm{~d} \partial \mathrm{k} \partial \mathrm{t}$ & $\mathrm{d} \supset \mathrm{ke}$ ? & $\mathrm{d} \partial \mathrm{kat}$ \\
\hline & $* \mathrm{ik} \partial \mathrm{t}$ & ike? & ikat \\
\hline
\end{tabular}
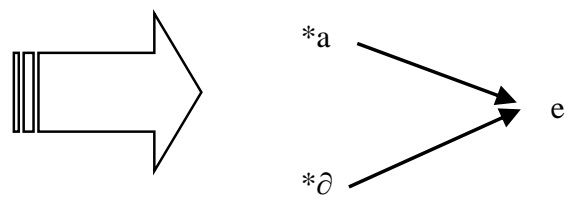

Dalam BS ditemukan adanya data *jahot > jaat (yang seharusnya menjadi jae?) belum dapat dijelaskan, tetapi ada kemungkinan bentuk ini diduga sebagai bentuk pinjaman, karena

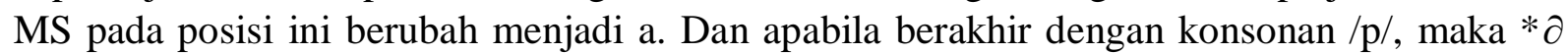
akan menjadi $\supset$ dalam BS dan berkorespondensi dengan a dalam MS.

\begin{tabular}{|c|c|c|}
\hline PM & BS & MS \\
\hline${ }^{*} \operatorname{hi}(\eta) \mathrm{s} \partial \mathrm{p}$ & is $\supset$ ? & isap \\
\hline *hat $\partial \mathrm{p}$ & at $\supset$ ? & atap \\
\hline$* a s \partial \mathrm{p}$ & as $\supset$ ? & asap \\
\hline
\end{tabular}

Adelaar (1992) menunjukkan bahwa PM: * $\partial$ mengalami retensi dalam bahasa Melayu Standard (MS), mengalami inovasi berupa substitusi secara teratur dalam BS menjadi $\supset$. Jadi, pada posisi ini, fonem / $/ \partial /$ pada MS berkorespondensi dengan $/ \supset /$ dalam BS.

\begin{tabular}{|c|c|c|}
\hline PM & BS & MS \\
\hline$* \mathrm{~d} \partial \mathrm{bu}$ & $\mathrm{d} \supset \mathrm{bu}$ & $\mathrm{d} \partial \mathrm{bu}$ \\
\hline *porut & pつi? & pôrut \\
\hline${ }^{*} \mathrm{~d} \partial \eta \partial \mathrm{r}$ & $\mathrm{d} \supset \eta \mathrm{a}$ & $\mathrm{d} \partial \eta \operatorname{mar}$ \\
\hline *bəli & bつli & bəli \\
\hline *sompit & $\mathrm{s} \supset \mathrm{mpi} ?$ & sompit \\
\hline
\end{tabular}

Menurut Adelaar (1992), PM: *i menjadi mengalami retensi dalam MS, dalam BS bunyi ini mengalami inovasi split yakni menjadi /i dan /e/, khusus pada posisi ultima tertutup terjadi secara teratur dan kedua fonem itu berkorespondensi dengan /i/ dalam MS.

$\begin{array}{clll}\text { (13) } \quad \text { BM } & \text { BS } & \text { MS } \\ & \text { *gigit } & \text { gigi? } & \text { gigit } \\ \text { *putih } & \text { putih } & \text { putih } \\ \text { *pilih } & \text { pilih } & \text { pilih } \\ \text { *pasir } & \text { pase } & \text { pasir } \\ \text { *b2nih } & \text { b } \supset \text { neh } & \text { bonih } \\ \text { *sisik } & \text { sise? } & \text { sisik }\end{array}$


Inovasi yang teramati lainnya, PM: *u khusus pada posisi ultima berakhir dengan /t/ $\mathrm{dan} / \mathrm{h} /$ mengalami inovasi berupa split (yaitu /i/ dan /ui/) dalam BS terjadi secara teratur dan dalam MS tetap dipertahankan sebagai u.

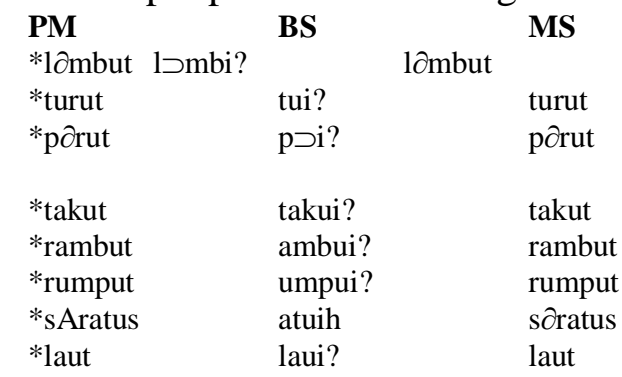

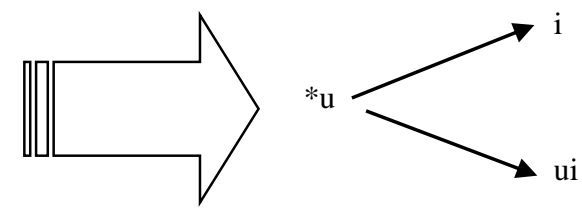

Inovasi menarik lainnya, adalah terjadi merger (penyatuan) bunyi *h dan *s pada PM menjadi /h/ dalam BS pada posisi ultima tertutup.

\begin{tabular}{|c|c|c|c|}
\hline PM & BS & MS & \\
\hline *darah & daah & darah & \\
\hline *dilah & lidah & lidah & $* \mathrm{~h}$ \\
\hline *bəlah & bつlah & bəlah & \\
\hline *poras & $\mathrm{p} \supset \mathrm{ah}$ & pôras & \\
\hline *tanis & tapih & tanis & *s \\
\hline *panas & paneh & panas & \\
\hline *tanis & tapih & tạis & $*_{\mathrm{s}}$ \\
\hline *panas & paneh & panas & \\
\hline
\end{tabular}

\section{b. Bukti Leksikon}

Ada beberapa contoh bukti leksikal yang dapat diajukan bahwa BS merupakan warisan dari PM, sebagai berikut.

\begin{tabular}{|c|c|c|c|}
\hline \multirow{8}{*}{ (16) } & PM & BS & GIOS \\
\hline & ${ }^{*}$ tanan & $\tan a n$ & \\
\hline & $\begin{array}{l}\text { *kairi } \\
\text { *jalan }\end{array}$ & $\begin{array}{l}\text { kii } \\
\text { ialan }\end{array}$ & $\begin{array}{l}\text { kiri } \\
\text { jalan }\end{array}$ \\
\hline & *hati & ati & \\
\hline & *gigi & gigi & gigi \\
\hline & *mata & matつ & mata \\
\hline & *rumah & umah & rumah \\
\hline & $* a t \partial p$ & at॰? & \\
\hline
\end{tabular}

Jadi berdasarkan bukti fonologis dan leksikon baik yang berupa retensi maupun inovasi yang disajikan di atas, merupakan bukti kuat untuk mengatakan bahwa BS termasuk isolek Melayu, yang kesamaan unsur-unsur kebahasaan bukan disebabkan pinjaman ataupun lebih banyak dipengaruhi isolek Melayu di sekitarnya, sehingga sulit untuk mengatakan bahwa BS bukan termasuk dalam rumpun bahasa Melayu. Dengan memanfaat 200 kosa kata dasar dalam MS dan MIN yang kumpulkan Adelar (1992:133), kemudian diperbandingkan ke dalam BS dengan mengacu pada kamus, dapat dilihat bahwa hampir sebagian besar kosa katanya memiliki banyak persamaan dan merupakan kosa kata Melayu.

\section{Hubungan Bahasa Sakai dengan Isolek Melayu Lainnya}

Ada dua hal yang harus dibicarakan dalam melihat hubungan BS dengan isolek Melayu lainnya, pertama kadar hubungan antara BS dengan isolek Melayu lainnya (paling tidak ada isolek Melayu tertentu yang memiliki kadar kedekatan yang tinggi dengan BS dan ada yang sebaliknya); kedua, BS memiliki ciri identitas kebahasan/kemelayuan yang berbeda, yang mem-bedakan dengan isolek Melayu lainnya, sekalipun isolek itu memiliki kadar kedekatan 
yang ting-gi dengan BS. Kedua hal di atas masing-masing mengimplikasikan bahwa, pertama ada sejumlah fakta kebahasaan yang menyatukan BS dengan isolek Melayu tertentu yang nota bene memiliki hubungan yang dekat, dan kedua, ada sejumlah fakta kebahasaan yang membedakan/memisahkan Bahasa Sakai dengan isolek lainnya. Jadi, ada bukti penyatuan yang menandai keeratan hubungan antara BS dengan salah satu isolek Melayu yang ada; dan ada bukti pemisahan yang membedakan BS dengan isolek-isolek Melayu itu. Istilah penyatuan di sini diartikan sebagai adanya ciri kebersamaan, inovasi bersama (shared innovation) yang menunjukkan kedekatan isolek-isolek itu, sedangkan istilah pemisahan dapat diartikan sebagai ciri yang membedakan BS dengan isolek Melayu lainnya (mungkin sebagai wujud hasil inovasi internal BS). Oleh karena itu, dua hal ini akan dibicarakan dalam bagian ini.

Perihal pendapat para linguis bahwa BS memiliki hubungan yang mirip bahasa Melayu dan Minangkabau, tampaknya masih harus dicermati karena masih menyimpan sejumlah persoa-lan. Artinya Apakah BS lebih dekat dengan bahasa Melayu (Melayu Riau) atau Minangkabau; atau BS memiliki kadar kedekatan yang sama dengan kedua isolek itu ?

Uraian di atas (4.1) telah sedikit memberikan penjelasan, bahwa bahasa Sakai memang merupakan varian bahasa Melayu, tetapi belum dapat ditentukan daerah asal bahasa Sakai atau mekanisme sosial yang menyebarkan BS ke wilayah Riau. Dalam uraian (bagian) Tinjauan Kajian Bahasa Sakai di atas, maka, penulis cenderung akan mengatakan bahwa BS memiliki hubu-ngan yang erat dengan bahasa Minangkabau daripada bahasa Melayu (Melayu Standard/Melayu Riau). Alasan pertama, menyangkut aspek historis, yaitu menyangkut Latar Belakang Sosial Budaya, yang oleh Lubis dkk (1985) dinyatakan bahwa suku Sakai berasal dari Pagaruyung, me-lalui Kota Intan (Kunto Darussalam) tiba di Mandau untuk menghindari peraturan pembayaran Pajak yang keras oleh Pemerintah Belanda, sedangkan Pagaruyung sendiri terdapat di Kabupaten Tanah Datar - Sumatra Barat yang merupakan salah satu wilayah pakai bahasa Minangkabau; dan kedua aspek linguistik, yakni ada sejumlah data yang turut memperkuat/menyokong berupa penyatuan, bahwa bahasa Sakai memiliki hubungan yang erat dengan bahasa Minangkabau. Berikut disajikan bukti kebahasan dimaksud. Tanah Datar merupakan salah satu dialek Minangkabau. Menurut Grimes (1994), Naim (1984) dalam Nadra (1997) Tanah Datar merupakan salah satu dialek Minangkabau.

\section{Bukti Penyatuan BS dengan Isolek Minangkabau}

Ada beberapa bukti penopang yang dapat diajukan bahwa BS memiliki hubungan yang erat dengan bahasa Minangkabau.

\section{Bukti Fonologi}

Proto Malayik *a mengalami inovasi bersama berupa split menjadi $\supset / o$ dan e dalam BS dan bahasa Minangkabau (MIN) pada posisi ultima terbuka, sedangkan dalam MS *a tetap mem-pertahankannya. Ini adalah bukti pemisah antara BS dan MIN dengan MS.

\begin{tabular}{|c|c|c|c|}
\hline PM & BS & MIN & MS \\
\hline *mata & mat $\supset$ & mato & mata \\
\hline *tAlina & 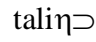 & talipo & telina \\
\hline *buna & buฑ & buүo & buๆa \\
\hline$*$ dua & duつ & duo & dua \\
\hline
\end{tabular}


Selain itu, bukti penyatuan BS dan MIN adalah adanya inovasi bersama (shared innovation) berupa merger, yakni fonem /o/ dan /e/ dalam BS dan MIN, pada posisi ultima yang berakhir dengan fonem /?/ berkorespondensi dengan fonem /a/ dalam MS.

$\begin{array}{lll}\text { MS } & \text { BS } & \text { MIN } \\ \text { bulat } & \text { b } \supset \text { le? } & \text { bale? } \\ \text { d } 2 \text { kat } & \text { d } \supset \text { ke? } & \text { dake? } \\ \text { ikat } & \text { ike? } & \text { ike? } \\ \text { (h)isap } & \text { is } \supset \text { ? } & \text { iso? } \\ \text { atap } & \text { at } \supset \text { ato? } & \text { at } \\ \text { asap } & \text { as } \supset \text { ? } & \text { aso? }\end{array}$

Hubungan yang menyatakan eratnya antara bahasa BS dengan MIN yang memisahkannya dengan MS, yakni adanya inovasi berupa merger dari BS dan MIN ke dalam MS, yaitu fonem /i/ dan /ui/ dalam BS - /uy/ dalam MIN berkorespondensi dengan /u/ dalam MS.

\begin{tabular}{|c|c|c|}
\hline MS & BS & MIN \\
\hline 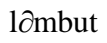 & $1 \supset \mathrm{mbi} ?$ & lombi? \\
\hline turut & tui? & tui? \\
\hline turut & p $\supset \mathrm{i} ?$ & poi? \\
\hline takut & takui? & takuy? \\
\hline rambut & ambui? & ambuy \\
\hline laut & lui? & lauy? \\
\hline
\end{tabular}

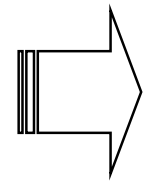

BS, MIN: ui, uy

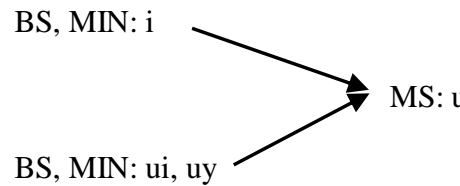

Keeratan antara BS dan MIN, yaitu fonem /p/ dan /?/ dalam BS dan MIN, pada posisi ultima secara teratur mengalami inovasi bersama berupa merger yakni menjadi MS: $\mathrm{p}$.

\begin{tabular}{|c|c|c|}
\hline MS & BS & MIN \\
\hline asap & asつ? & aso? \\
\hline sayap & say $\supset$ ? & sayo? \\
\hline hadap & $\mathrm{ad} \supset ?$ & ado? \\
\hline hidup & idup & idup \\
\hline 12) ap & 1つ>ap & la $>$ ap \\
\hline sədap & sつdap & sadap \\
\hline
\end{tabular}

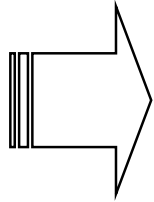

BS, MIN: q

BS, MIN: $p$

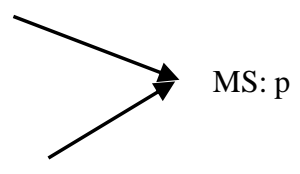

Selain itu, fonem /?/ BS dan MIN berkorespondensi dengan /t/ dan /k/ dalam MS, seperti pada BS dan MIN terdapat angke?, a/ompe?, jai?, poi?, gigi?, ike?, ana?, masa?, panda?, dsb. secara berturut dalam MS, muncul sebagai angkat, ampat, jahit, perut, gigit,

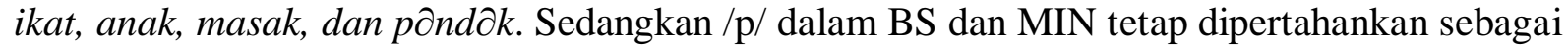
/p/. Jadi dapat dikatakan /?/ dalam BS dan MIN mengalami merger parsial dalam MS.

(21) BS, MIN: p

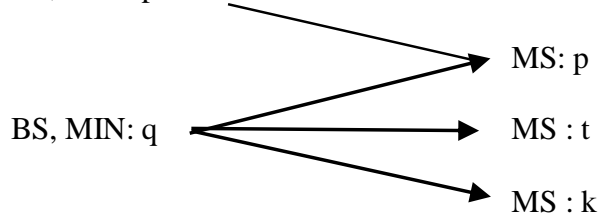

Bukti yang memperkuat penyatuan BS dan MIN adalah hilangnya fonem *h dalam PM pada posisi awal dan tengah dan hanya dipertahankan pada posisi akhir, sedangkan dalam MS tetap dipertahankan pada semua posisi.

\begin{tabular}{|c|c|c|}
\hline MS & BS & MIN \\
\hline hitam & itam & itam \\
\hline hidu & idu & idu \\
\hline jahit & jai? & jai? \\
\hline dahan & daan & daan \\
\hline
\end{tabular}


Terjadinya inovasi bersama dari PM: *s, terjadi secara teratur menjadi h dalam BS dan MIN, sedangkan dalam MS secara teratur tetap dipertahankan sebagai /s/ pada semua posisi.

\begin{tabular}{|c|c|c|}
\hline PM & BS & MIN \\
\hline *tanis & tạih & tanih \\
\hline *panas & paneh & paneh \\
\hline *nipis & tipih & tipih \\
\hline
\end{tabular}

\section{Bukti Leksikon}

Berdasarkan pengamatan, ternyata ditemukan sejumlah bukti leksikal yang mendukung bahwa BS memiliki hubungan yang erat dengan MIN dibandingkan dengan MS, yaitu terjadinya inovasi bersama dalam sejumlah leksikon

\begin{tabular}{|c|c|c|c|}
\hline \multirow{11}{*}{ (24) } & BS & MIN & MS \\
\hline & kumuh & $\mathrm{kumu}^{\partial} \mathrm{h}$ & kotor \\
\hline & gala? & gola? & tortawa \\
\hline & bagulin & bagule? & bərbari \\
\hline & tつga? & taga? & bordiri \\
\hline & muncuך & $\operatorname{muncu}^{\partial} \eta$ & mulut \\
\hline & ameh & rameh & poras \\
\hline & $\mathrm{ik} \supset$ & iko & ini \\
\hline & bil $\supset$ & bilo & kapan \\
\hline & panda? & panda? & pônd $\partial ?$ \\
\hline & padusi & padusi & pordmpuan \\
\hline
\end{tabular}

\section{Bukti Pemisahan BS dengan isolek Melayu Lainnya}

Sebagai bahasa yang secara geografis memiliki perbedaan dan sebagai akibat melalui proses perkembangan/sejarah yang berbeda, tentunya dalam BS ditemukan sejumlah ciri khas yang membedakan dengan isolek Melayu lainnya (salah satunya melalui inovasi internal). Pada bagian ini akan ditunjukkan adanya perbedaan/pemisahan (ciri penanda kebahasaan) antara bahasa Sakai dengan isolek Melayu lainnya dalam hal ini, isolek Minangkabau dan Melayu Standard baik pada aspek fonologis maupun leksikal, yang menandai bahwa, BS merupakan isolek tersendiri, yang berbeda dengan isolek lain seperti Minangkabau maupun Melayu Riau.

Ciri di bidang fonologi, ditemukan proses perubahan bunyi secara teratur dalam bahasa Melayu Riau, Bahasa Sakai, dan bahasa Minangkabau, yaitu fonem e (pepet) dalam MS berkorespondsi dengan /a/ dan berkorespondensi $/$ / dalam BS, pada posisi penultima terbuka/tertutup $(\mathrm{MS} \approx \mathrm{BS} \approx \mathrm{MIN}: \mathrm{e} \approx \supset \approx \mathrm{a} / \# \mathrm{KV}(\mathrm{K})-$ ).

\begin{tabular}{|c|c|c|}
\hline MS & MIN & BS \\
\hline $\mathrm{d} \partial \mathrm{bu}$ & $\mathrm{abu}$ & $\mathrm{d} \supset \mathrm{bu}$ \\
\hline porut & paruy? & pつi? \\
\hline bəlah & balah & bつlah \\
\hline $1 \partial \mathrm{mak}$ & lama? & $l \supset \mathrm{ma} ?$ \\
\hline $\mathrm{t} \partial \mathrm{bal}$ & tabal & $\mathrm{t} \supset \mathrm{bal}$ \\
\hline bəanar & bana & $\mathrm{b} \supset$ na \\
\hline ompat & ampe? & $\supset$ mpeq \\
\hline $\mathrm{d} \partial \mathrm{kat}$ & dake? & $\mathrm{d} \supset \mathrm{ke}$ ? \\
\hline
\end{tabular}

Sedangkan ciri di bidang leksikal yang membedakan antara BS dengan isolek Melayu Standard dan Minangkabau sebagai berikut.

\begin{tabular}{|c|c|c|c|}
\hline \multirow{6}{*}{ (26) } & MS & MIN & BS \\
\hline & kulit & kuli? & jạe? \\
\hline & bahu & bau & kakapi \\
\hline & anji $\eta$ & anji $\eta$ & kuju? \\
\hline & danaw & danaw & $\mathrm{d} \supset \mathrm{n} \supset \eta$ \\
\hline & eๆkau & aךkau & $\supset \mathrm{mp} \supset \mathrm{n}$ \\
\hline
\end{tabular}


Dengan adanya bukti fonologis dan leksikal di atas itu berarti bahwa bahasa Sakai memang memiliki hubungan yang lebih rapat/erat dengan MIN dibandingkan Melayu Standard; malah dapat dikatakan kedua isolek itu (BS dan MIN) merupakan dua varian dari dialek bahasa yang sama. Namun, harus disadari bahwa tinjauan ini adalah tinjauan linguistik diakronis/historis. Karena isolek itu memiliki letak geografis dan melalui perkembangan yang berbeda, sehingga dimungkinkan terjadinya perubahan. Perubahan itu dapat mengakibatkan terjadinya perbedaan dalam kedua varian, kemudian menyebabkan kadar kesalingmengertian antara kedua isolek itu rendah. Maka, dari perspektif sosiolinguistik kontemporer wajar jikalau varian Sakai diistilahkan bahasa Sakai. Tetapi, berstatus apapun varian itu pada periode ini, hal itu tidak mempengaruhi identitasnya sebagai subdialek Sakai-Minangkabau.

\section{PENUTUP}

Berdasarkan kenyataan bahwa semua inovasi yang ditemukan Dempwolf berupa inovasi khusus PAN ke dalam bahasa Melayu dan refleks PM ke dalam BS yang berupa inovasi dalam uraian di atas cukup bukti untuk mengatakan bahwa BS merupakan kelanjutan dari Proto Malayik. Sedangkan persamaan leksikon dan korespondensi inovasi dan sporadis, dapat disimpul-kan bahwa BS dan MIN adalah dua varian dari bahasa yang sama, walaupun juga terdapat per-bedaan antara dua varian itu, sehingga mewajibkan kita untuk menerima kenyataan bahwa bahasa Sakai adalah bahasa Melayu.

Dengan teridentifikasinya asal-usul bahasa Sakai, maka bertambah jelas gambaran seluruh silsilah bahasa Melayu. Penemuan silsilah bahasa Sakai bukan hanya sekadar peningkatan statisik sensus bahasa, tetapi dengan menentukan bahasa Sakai sebagai varian bahasa Melayu di Riau (Daratan), kita dapat menemukan alat yang efektif untuk mengukur dialek Melayu lain di wilayah sekitarnya. Kajian tentang bahasa Sakai dari aspek linguistik diakronis membawa implikasi bahwa bahasa dan dialek daerah yang jauh dari pusat pemerintahan dan pembudayaan wajar bila sering memperlihatkan keanehan dan penyimpangan, jika dibandingkan dengan varian dominan dan varian pusat.

\section{DAFTAR PUSTAKA}

Adelaar, K.A. (2005). Malayo-Sumbawan. Oceanic Linguistics Journal, 44(1). 357-388. https://doi.org/10.1353/ol.2005.0027

Adelaar, K Alexander. (1992). Proto Malayic: The Reconstruction of its Phonology and Parts of its Lexicon and Morphology. Alblasserdam: Offsetdrukkerij Kanters BV.

Anceaux, J.C. (1981). Teori-Teori Linguistik tentang Tanah Asal Bahasa Austronesia, terjemahan dari Linguistics Theories about the Austronesian Homeland oleh Sudaryanto, Bacaan Linguistik: Nomor 4. Yogyakarta: Komisariat MLI UGM.

Blust, Robert. (1988). Malay Historical Linguistics: A Progress Report dalam Rekonstruksi dan Cabang-cabang Bahasa Melayu Induk. Kuala Lumpur: Dewan Bahasa dan Kementerian Pendidikan Malaysia.

Blust, Robert A. (1993). Central and Central-Eastern Malayo-Polynesian. Oceanic Linguistics Journal, 32(2). 241-293. https://doi.org/10.2307/3623195

Blust, Robert A. (2009). Position of the Languages of Eastern Indonesia: A Reply to Donohue and Grimes. Oceanic Linguistics Journal, 48. 36-77. https://doi.org/10.1353/ol.0.0034

Blust, Robert A. (2012(. The Marsupials Strike Back: A Reply to Schapper (2011). Oceanic Linguistics Journal, 51. 261-277. https://doi.org/10.1353/ol.2012.0000

Blust, Robert A. (2013). The Austronesian Languages. Revision Edition. Canberra: Pacific Linguistics.

Collins, James T. (1994). Dialek Melayu di Kalimantan, dan Bahasa Bacan: Misanan atau Mindoan. Dalam Pellba 8. Disunting oleh Soenjono Dardjowidjojo. Jakarta: Lembaga Bahasa Unika Atma Jaya.

Collins, James T. (1983). Penggolongan Bahasa Melayu Bacan. Dalam Pellba 8. Disunting oleh Soenjono Dardjowidjojo. Jakarta: Lembaga Bahasa Unika Atma Jaya.

Dahlan, dkk. (1985). Pemetaan Bahasa Daerah Riau dan Jambi. Jakarta: Pusat Pembinaan dan Pengembangan Bahasa.

Donohue, Mark, and C.E. Grimes. (2008). Yet More on the Position of the Languages of Eastern Indonesia. Oceanic Linguistics Journal, 47. 114-158. https://doi.org/10.1353/ol.0.0008 
Fernandez, Inyo. (1996). Relasi Historis Kekerabatan Bahasa Flores Kajian Linguistik Historis Komparatif terhadap Sembilan Bahasa di Flores. Flores: Nusa Indah.

Fernandez, Inyo. (1997). Wajah Melayu pada Bahasa Manado dan Bahasa Nagi Kajian Aspek Diakronis Perbandingan Dua Dialek Melayu di Kawasan Timur Indonesia di Bidang fonologi, Morfologi, dan Leksikon. Makalah Tidak diterbitkan. Yogyakarta: Universitas Gadjah Mada.

Fernandez, Inyo. (1998). Melayu Larantuka di Flores Timu: Sebuah Tinjauan dari Persfektif Sejarah; dan Beberapa Catatan tentang Bahasa Melayu Dilli: Studi Awal Mengenai Bahasa Melayu di Timor Timur. Makalah Tidak diterbitkan. Yogyakarta: Universitas Gadjah Mada.

Gani, Abdul dkk. (1985). Kamus Sakai - Indonesia. Jakarta: Pusat Pembinaan dan Pengembangan Bahasa.

Hadi, Paesal; Burhanuddin; dan Sukri. 2020. PAN Reflex in Maya Language in West New Guinea: A Preliminary Study on Understanding The Concept of South Halmahera-West New Guniea. Proceedings of the 4th International Conference on Language, Literature, Culture, and Education (ICOLLITE). Atlantis Press. https://doi.org/10.2991/assehr.k.201215.081

Kawi, Djantera. (1991). Kajian Komparatif Bahasa Nusantara. Jakarta: Lembaga Bahasa dan Ketahanan Nasional.

Keraf, Gorys. (1984). Linguistik Bandingan Historis. Jakarta: Gramedia Pustaka Utama.

Lubis, Idrus dkk. (1985). Struktur Bahasa Sakai. Jakarta: Pusat Pembinaan dan Pengembangan Bahasa.

Kompas. (2003). Sebuah Kamus untuk Warga Sakai karangan Hans Kalipke. Jakarta: Harian Kompas, 03 Januari 2003.

Martono, Sugiyo Hadi dkk. (1995). Morfologi dan Sintaksis Bahasa Sakai. Jakarta: Pusat Pembinaan dan Pengembangan Bahasa.

Mbete, Aron Meko. (1990). Rekonstruksi Proto Bahasa Bali-Sasak-Sumbawa. Disertasi Doktor. Jakarta: Universitas Indonesia.

Nadra, (1997). Geografi Dialek Bahasa Minangkabau. Disertasi Doktor. Yogyakarta: Universitas Gadjah Mada.

Nothofer, (1986). A Discucion of Two Austronesian Subgroups: Proto-Malay and Proto Malayic. Dalam Rekonstruksi dan Cabang-cabang Bahasa Melayu Induk. Kuala Lumpur: Dewan Bahasa dan Kementerian Pendidikan Malaysia.

Nothofer, (1988). A Discucion of Two Austronesian Subgroups: Proto-Malay and Proto Malayic. Dalam Rekonstruksi dan Cabang-cabang Bahasa Melayu Induk. Kuala Lumpur: Dewan Bahasa dan Kementerian Pendidikan Malaysia.

Nothofer, Bern. (1992). Central Melayo Poynesian and Central-East Melayu Polynesian: Two Subgroup? Oceanic Linguistics Journal, 21(1).

Nothofer, (1995). Dialek Melayu di Kalimantan dan di Bangka Misan atau Mindoan. Dalam Pellba 8. Penyunting Soenjono Dardjowidjojo. Jakarta: Lembaga Bahasa Unika Atma Jaya.

Sarwadi, Gita; Mahsun; dan Burhanuddin (2019). Lexical Variation of Sasak Kuto-Kute Dialect in North Lombok District. Jurnal Kata: Penelitian tentang Ilmu Bahasa dan Sastra, 3(1), 155-169. https://doi.org/10.22216/kata.v3i1.4142

Schapper, Antoinette. (2011). Phalanger Facts: Notes on Blust's Marsupial Reconstruction. Oceanic Linguistics Journal, 50, 258-272. https://doi.org/10.1353/ol.2011.0004

Sumarlam; Purnanto, Dwi; dan Burhanuddin. (2018). Reflex Proto-Austronesia to Ambelau in West Central Maluku Group: the Effort to Test the Hipotesis Collins (1981). Proceedings of the Fourth Prasasti International Seminar on Linguistics (Prasasti). Atlantis Press. https://doi.org/10.2991/prasasti$\underline{18.2018 .58}$

Sumarlam, dkk. (2017). Urgensi Studi Linguistik Historis Terhadap Kelompok Maluku Tengah Barat: Beberapa Catatan Studi Pendahuluan Collins (1981). Arkhais: Jurnal Ilmu Bahasa dan Sastra Indonesia, 8(2), 101110. https://doi.org/10.21009/ARKHAIS.082.02

Sumarlam, dkk. (2017). Reflexes of Proto-Austronesia into Buru Language: Preliminary Step of Testing Collins Hypothesis (1981). Proceedings of the Sixth International Conference on Languages and Arts (ICLA). Atlantis Press. 